University of Nebraska - Lincoln

DigitalCommons@University of Nebraska - Lincoln

Mammalogy Papers: University of Nebraska

State Museum

Museum, University of Nebraska State

2009

Recent Occurrence of an American Black Bear in Nebraska

Justin D. Hoffman

McNeese State University, jhoffman@mcneese.edu

Sam Wilson

Nebraska Game and Parks Commission

Hugh H. Genoways

University of Nebraska-Lincoln, h.h.genoways@gmail.com

Follow this and additional works at: https://digitalcommons.unl.edu/museummammalogy

Part of the Biodiversity Commons, and the Zoology Commons

Hoffman, Justin D.; Wilson, Sam; and Genoways, Hugh H., "Recent Occurrence of an American Black Bear in Nebraska" (2009). Mammalogy Papers: University of Nebraska State Museum. 132.

https://digitalcommons.unl.edu/museummammalogy/132

This Article is brought to you for free and open access by the Museum, University of Nebraska State at DigitalCommons@University of Nebraska - Lincoln. It has been accepted for inclusion in Mammalogy Papers: University of Nebraska State Museum by an authorized administrator of DigitalCommons@University of Nebraska Lincoln. 


\section{Recent occurrence of an American black bear in Nebraska}

\author{
Justin D. Hoffman ${ }^{1}$, Sam Wilson ${ }^{2}$, and Hugh H. \\ Genoways $^{3}$ \\ ${ }^{1}$ Department of Biology, McNeese State University, Lake \\ Charles, LA 70609, USA \\ ${ }^{2}$ Nebraska Game and Parks Commission, 2200 N 33 $3^{\text {rd }}$ \\ Street, Lincoln, NE 68503, USA \\ ${ }^{3}$ University of Nebraska State Museum, W436 Nebraska \\ Hall, Lincoln, NE 68588-0514, USA
}

Abstract: We report on a young male, cinnamonphase American black bear (Ursus americanus) that was collected in northwestern Nebraska on 12 May 2008. This specimen represents the first black bear taken in Nebraska since 1907. Cranial characteristics and mass of the individual indicated a 15-16 month old bear. This bear may have dispersed from the Laramie Mountains in southeastern Wyoming along the North Platte River into western Nebraska. This record adds to the growing number of cases where large carnivores are reinvading previously occupied territory in the Great Plains. These reinvasions potentially have broad ecological implications to local prey populations and overall biodiversity.

Key words: American black bear, Great Plains, Nebraska, range expansion, Ursus americanus

Ursus 20(1):69-72 (2009)

On 12 May 2008, a young male, cinnamon-phase American black bear (Ursus americanus) was collected at the Grote Ranch about 6.5 kilometers (4 miles) north of Harrison, Sioux County, in extreme northwestern Nebraska (Fig. 1; Rempp 2008). We believe that this is the same bear that evaded authorities in eastern Wyoming on 7 May 2008 when it was observed and photographed along the North Platte River southwest of Torrington, Goshen County. Wyoming Game and Fish Department officials speculated that the bear originated in the area of Laramie Peak, Albany County, west of Torrington (Bottrell 2008). The bear was first seen on 12 May 2008 in the late afternoon as it encountered several residences of Harrison. Later that same day it was seen by the owner of Grote Ranch, who trapped it in a barn. The decision was made by the Nebraska Game and Parks Commission to sacrifice the animal as it seemed to not be wary of humans. This was the first black bear collected in Nebraska in over 100 years.

The skull, partial skeleton, and skin of this specimen are housed in the zoology collection of the University of Nebraska State Museum (ZM-29171). The braincase of the specimen was damaged during collection so that only a few of the standard cranial measurements could be obtained: length of nasals, $64.5 \mathrm{~mm}$; interorbital breadth, $52.0 \mathrm{~mm}$; breadth across upper canines, $52.5 \mathrm{~mm}$; length of upper molar M2, $22.4 \mathrm{~mm}$; width of upper molar M2, $14.4 \mathrm{~mm}$; length of maxillary tooth row (canine-M2), $86.8 \mathrm{~mm}$; length of mandible, $162.4 \mathrm{~mm}$; length of mandibular tooth row (c-m3), $99.0 \mathrm{~mm}$.

All permanent dentition of the individual was fully erupted, which normally occurs in a bear's first year. Bears 1-2 years old were termed yearlings by Marks and Erickson (1966:391). One of the main characteristics of this group was a body weight of 24-55 $\mathrm{kg}$ (53-121 pounds), with a mean of $41.6 \mathrm{~kg}$ (91.7 pounds); our specimen weighed $40.8 \mathrm{~kg}$ (90 pounds). Finally, the dentino-enamel junction of the upper canines was exposed above the alveolar margin, another important characteristic of yearling bears. Based on these characteristics, we believe that this bear was a yearling and given that most bears are born in late January-early February (Marks and Erickson 1966:391), it would have been 15-16 months old.

Two other recent sightings of black bears also were reported from extreme western Nebraska near the Wyoming border with Harrisburg, Banner County in 2000 and near Henry, Scotts Bluff County in 2002 (Fig. 1; Hoffman and Genoways 2005). Bottrell (2008) indicated that the latter animal reentered Wyoming and was finally captured near Cheyenne, Laramie County, approximately $120 \mathrm{~km}$ southwest of Henry. Hoffman and Genoways (2005) hypothesized that these bears were dispersing into western Nebraska from the Laramie Mountains along the North Platte River in Wyoming.

The last black bear taken in the state was in the winter of 1907 near Valentine, Cherry County (Swenk 1908:124, Jones, 1964). The earliest records of American black bears in Nebraska were all from along the Missouri River (Fig. 1), with the first coming from William Clark's miscellaneous natural history notes (written in 1806) where he states: "The Black Bear is found in abundance as high as the little 


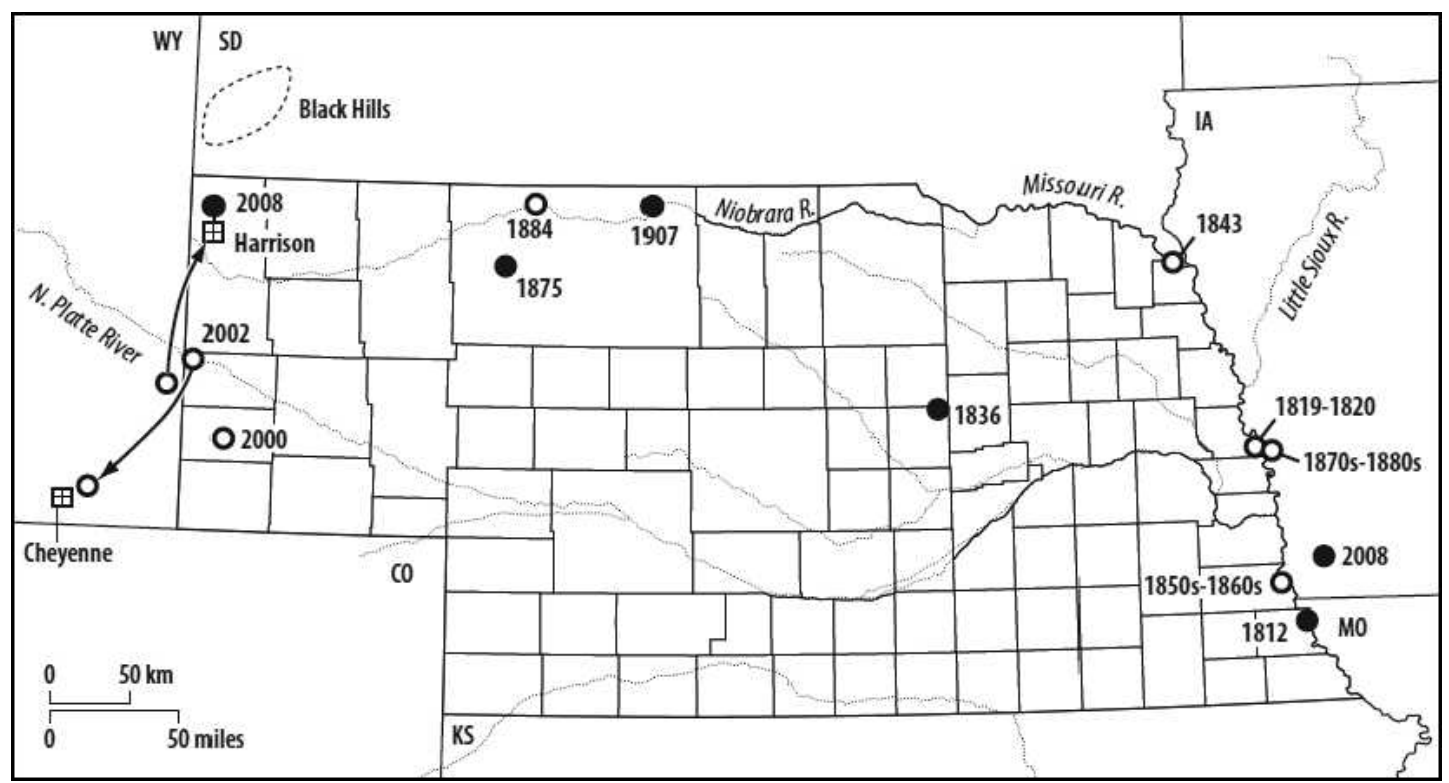

Fig. 1. Yearly records of the American black bear (Ursus americanus) in Nebraska, 1812-2008. Closed circles are places where black bears have been taken; open circles are places where black bears or their sign were observed.

Sioux river" (Moulton 1993:416). Subsequent records of black bears from along the Missouri River include those of Luttig (1920:41) from Nemaha County (21 May 1812), James (1823:369; Genoways and Ratcliffe 2008) from Washington County (1819 20), Audubon and Coues (1897:489) from Dakota County (14 May 1843), Aughey (1880:118) from Otoe County, (1850s-1860s), and Swenk (1908:124), who reported bear tracks in the vicinity of Rockport, Washington County (1870s-1880s).

Black bears have been reported in north-central Nebraska in the central Niobrara River region and the upper Loup River (Fig. 1). The earliest record of a black bear from that part of the state was shot on 14 January 1836 (Allis 1918:707; Jones 1962:92), probably in northern Greeley County (Jones 1962:92). Foght (1906:68) reported a large bear taken in 1875 in west-central Cherry County. Swenk $(1908: 124)$ reported tracks of bear seen along Bear Creek near Cody, Cherry County, in 1884. The only other reference to bears along the Niobrara River was a black-phase bear seen by Aughey (1880:118) at an unspecific location probably in the 1860s. Not mapped in Fig. 1 is a record from an Upper Republican archeological site (25FT13, AD 1015) where the remains of a black bear were recovered from a trash midden near the modern day Medicine Creek Dam in southwestern Frontier County (Kivett and Metcalf 1997:173).

There are no recent records of the American black bear in eastern Nebraska; however, Iowa wildlife officials had 5 sightings of bears in the western part of the state during 2008. A $90.7 \mathrm{~kg}$ (200 pound) male was taken in late June in Sidney, Fremont County, Iowa (Fig. 1; Hammel 2008). The sources of these bears probably are either the boreal forest region of northern Minnesota (Garshelis 2008) or the introduced population in Ozark Mountains of Missouri (Hamilton and Martensen 2008:15).

This new record of an American black bear in Nebraska adds to a growing list of long-extirpated species of carnivores that are reappearing in the state. Hoffman and Genoways (2005) documented recent records of the wolf (Canis lupus), mountain lion (Puma concolor), and Canadian lynx (Lynx canadensis) in Nebraska. At this point, probably only the mountain lion has established a permanent population in Nebraska (unpublished data). The reasons behind the reappearance of these longextirpated species seem to be similar. In source areas, populations of these carnivores are building 
because of improved species and habitat management. As these populations approach or exceed carrying capacity, young individuals, especially males that are unable to establish territories begin to wander in search of uninhabited appropriate habitat. Suitable habitat for these species has been expanding in recent years in Nebraska. Although the vast majority of land in Nebraska is private, riparian forests are expanding across the state from east to west along major river systems including the Niobrara, Platte, Republican, and Missouri (Johnson 1994). Riparian forests provide cover for these species and an almost unbroken dispersal corridor to and across the state.

The continued expansion of large carnivores, such as the American black bear, into previously unoccupied habitats will undoubtedly have various ecological implications. Keystone predators can have broad effects on ecosystems by regulating prey populations and maintaining biodiversity (Berger et al. 2001). How ecosystems respond to the reinvasion of large predators provides opportunities to study predator-prey interactions and how these interactions affect ecosystem biodiversity.

\section{Acknowledgments}

We thank J.D. Hoffman, T. Nordeen, and D. Darveau from the Nebraska Game and Parks Commission for assisting us in gaining access to the specimen. We thank T.E. Labedz and A. Fox of the University of Nebraska State Museum for preparing the specimen and the figure, respectively.

\section{Literature cited}

Allis, S. 1918. Letters concerning the Presbyterian Mission in the Pawnee country, near Bellevue, Neb, 1831-1849-Letters from Samuel Allis, May 3, 1834, to January 16, 1849. Collections of the Kansas State Historical Society 14:690-741.

Audubon, M.R., And E. Coues. 1897. Audubon and his journals. Charles Scribner's Sons, New York, New York, USA. Reprinted 1986, Dover Publications, Mineola, New York, USA.

Aughey, S. 1880. Sketches of the physical geography and geology of Nebraska. Daily Republican Book and Job Office, Omaha, Nebraska, USA.

Berger, J., P.B. Stacey, L. Bellis, and M.P. Johnson. 2001. A mammalian predator-prey imbalance: grizzly bear and wolf extinction affect avian neotropical migrants. Ecological Applications 11:947-960.
Bottrell, K. 2008. Black bear sighted in North Platte River eludes capture. The Torrington Telegram Online, Torrington, Wyoming, USA. http://www. torringtontelegram.com/, accessed 9 May 2008.

Foght, H.W. 1906. The trail of the Loup, being a history of the Loup River region with some chapters on the state. Privately published, Ord, Nebraska, USA.

Garshelis, D. 2008. Status of Minnesota black bears, 2007. Minnesota Department of Natural Resources, St. Paul, Minnesota, USA.

Genoways, H.H., and B.C. Ratcliffe. 2008. Engineer Cantonment, Missouri Territory, 1819-1820: America's first biodiversity inventory. Great Plains Research 18:3-31

Hamilton, D., and R. Martensen. 2008. Be bear wise in Missouri? Yes! Missouri Conservationist 69(1): $14-17$.

Hammel, P. 2008. Bear policy pondered for Nebraska, Iowa. Omaha-World Herald, 3 July 2008, http:// www.omaha.com/index.php?u_page $=2798 \&$ u_sid $=$ 10372622 .

Hoffman, J.D., and H.H. Genoways. 2005. Recent records of formerly extirpated carnivores in Nebraska. Prairie Naturalist 37:225-245.

James, E. 1823. Account of an expedition from Pittsburgh to the Rocky Mountains, performed in the years 1819 and '20, by order of the Hon. J. C. Calhoun, Sec'y of War: Under the command of Major Stephen H. Long, from the notes of Major Long, Mr. T. Say, and other gentlemen of the exploring party. H.C. Carey and I. Lea, Philadelphia, Pennsylvania, USA. Reprinted, Readex Microprint Corporation, New York, New York, USA 1966.

Johnson, W.C. 1994. Woodland expansion in the Platte River, Nebraska: patterns and causes. Ecological Monographs 64:45-84.

JONES, J.K., JR. 1962. Early records of some mammals from Nebraska. Bulletin of the University of Nebraska State Museum 4:89-100.

. 1964. Distribution and taxonomy of mammals of Nebraska. University of Kansas Publications, Museum Natural History 16:1-356.

Kivett, M.F., and G.S. Metcalf. 1997. The prehistoric people of the Medicine Creek Reservoir, Frontier County, Nebraska: An experiment in mechanized archeology (1946-1948). Plains Anthropologist 42:i-v, $1-218$.

LutTig, J.C. 1920. Journal of a fur-trading expedition on the Upper Missouri, 1812-1813. S.M. Drumm, editor, Missouri Historical Society, St. Louis, Missouri, USA. Reprinted 1964, Argosy-Antiquarian, New York, New York, USA.

Marks, S.A., ANd A.W. ERICKSON. 1966. Age determination in the black bear. Journal of Wildlife Management 30:389-410. 
Moulton, G.E., EDITOR. 1993. The Journals of the Lewis and Clark Expedition, June 10-September 26, 1806. University of Nebraska, Lincoln, Nebraska, USA.

Rempr, K. 2008. Bear makes himself at home in Harrison. The Chadron Record 13 May 2008, http:// www.thechadronnews.com/articles/2008/05/13/chadron/ headlines/news966.txt.
SwENK, M.H. 1908. A preliminary list of the mammals of Nebraska, with synopses. Proceedings of the Nebraska Academy of Sciences 8:61-144.

Received: 3 December 2008

Accepted: 6 January 2009

Associate Editor: R. Harris 